\title{
INTERFERÊNCIA DO PODER JUDICIÁRIO NA REGULAÇÃO DO MERCADO DE VALORES MOBILIÁRIOS: CASO DA TRANSPARÊNCIA DA REMUNERAÇÃO DOS ADMINISTRADORES NO BRASIL
}

\author{
JUDICIARY INTERFERENCE OVER THE REGULATION OF SECURITIES MARKET: \\ THE CASE OF EXECUTIVES’ REMUNERATION DISCLOSURE IN BRAZIL
}

Viviane Muller Prado*

\begin{abstract}
RESUMO
O objetivo deste texto é trazer elementos para refletir se e como o Poder Judiciário participa da regulação do mercado de capitais editada pela Comissão de Valores Mobiliários (CVM). O estudo é feito a partir da análise do único caso relevante nos últimos dez anos sobre divulgação de informação da remuneração dos administradores de companhias abertas. Os principais achados da pesquisa são os seguintes: (1) apesar de o Judiciário não ser chamado constantemente a se posicionar sobre as novas regras administrativas editadas pela CVM, há grande potencial da sua interferência tendendo à proteção de interesses individuais em contraposição a políticas regulatórias para desenvolvimento do mercado de valores mobiliários, especialmente em sede liminar; (2) a decisão judicial de proteção dos direitos individuais em prejuízo às políticas regulatórias da CVM pode ser mitigada por iniciativas dos participantes do mercado, sejam eles os investidores ou as próprias companhias listadas; e, por fim, (3) no processo de internalização de padrões regulatórios internacionais, o Judiciário pode ser a instituição local que faz a ponderação e analisa a adequação da regra ao sistema jurídico brasileiro.
\end{abstract}

\section{PALAVRAS-CHAVE}

Poder Judiciário. Comissão de Valores Mobiliários. IOSCO. Remuneração dos administradores.

\begin{abstract}
This paper aims to shed light on the role of the Judiciary in the Brazilian capital markets regulation. The study is based on the analysis of the only important case in the last ten years that shows there is great potential for judicial interference. This interference, through injunctions, tends to favour the protection of individual rights over regulatory policies for the development of the securities market. However, the case shows that judicial decisions for the protection of individual rights contrary to CVM regulatory policies can be mitigated by initiatives of market participants, whether they are investors or listed companies. The case study suggests that in the process of internalizing international regulatory standards the judiciary may be the local institution to consider and analyse the suitability of rules in the Brazilian judicial system.
\end{abstract}

\section{KEYWORDS}

Judiciary. Securities Commission. IOSCO. Executive Remuneration.

\footnotetext{
* Graduada em Direito pela Universidade Federal do Paraná (1995). Doutora em Direito Comercial pela Universidade de São Paulo (2004). Professora da Escola de Direito de São Paulo - Fundação Getúlio Vargas (Direito GV, São Paulo, SP, Brasil). E-mail: viviane.prado@fgv.br
} 


\section{INTRODUÇÃO}

Após a crise financeira de 2008, o tema da remuneração dos administradores ganhou relevância e ficou evidente a sua relação com os estímulos dados aos gestores a correr ou não riscos excessivos $^{1}$. Nos foros internacionais, houve forte pressão para que os reguladores criassem regras sobre remuneração dos executivos em companhias que acessam o mercado de capitais.

Essa pressão atingiu a Comissão de Valores Mobiliários (CVM), autarquia competente para a regulação do mercado de valores mobiliários brasileiro. Dando seguimento à regulação que aperfeiçoou enormemente a transparência de companhias abertas brasileiras², em 2008 a CVM propôs novo ato normativo, exigindo a divulgação ao público dos valores da remuneração dos principais executivos das companhias abertas. Durante a audiência pública, houve grande resistência à proposta, dado que afetaria interesses particulares dos tomadores de decisão das grandes empresas brasileiras. Os posicionamentos contrários à norma apoiaram-se em argumentos culturais e de segurança pública. Após ouvir as manifestações, a CVM modificou a exigência e determinou a divulgação dos valores máximos, mínimos e médios das remunerações dos administradores, sem ligação direta entre nomes e números.

Alguns meses após a publicação da norma, uma associação de executivos acionou o Poder Judiciário e obteve liminar garantindo aos seus associados o direito à não publicidade de tal informação. Após muitos recursos judiciais, a decisão contrária à CVM foi mantida. Tal decisão apenas beneficia companhias e indivíduos filiados à associação autora da ação. Como resultado, atualmente há no Brasil companhias obrigadas a divulgar e outras que, utilizando-se do amparo judicial, não fornecem informação, ao mercado, sobre a remuneração de seus administradores.

Esse é o único caso nos últimos dez anos no qual o Poder Judiciário foi chamado a posicionar-se sobre a criação de normas administrativas da CVM relevantes para o aperfeiçoamento

\footnotetext{
1 Para acesso aos principais estudos produzidos recentemente sobre este tema, ver: EUROPEAN CORPORATE GOVERNANCE INSTITUTE. Executive Remuneration. 30 jun. 2003. Disponível em: $<$ http://www.ecgi.org/remuneration/>. Acesso em: 14 jun. 2015.

${ }^{2} \mathrm{O}$ ponto de partida para a modernização do regime de divulgação de ampla informação no Brasil iniciou-se com a Lei 10.303/2001 (que possibilitou que a CVM classificasse companhias em diferentes categorias, sujeitas a disciplinas diversas). Essa lei foi seguida por outros normativos: Instrução CVM 358/2002 (sobre divulgação de atos e fatos relevantes); Instrução CVM 400/2003 (sobre informações dadas para o registro de ofertas públicas de distribuição de valores mobiliários nos prospectos); Instrução CVM 480/2009 (sobre registro de emissores de valores mobiliários e informações que devem ser dadas ao mercado em documento denominado Formulário de Referência); Instrução CVM 481/2009 (informações das companhias dadas antes das assembleias gerais); Lei 11.638/2007 (regras sobre elaboração de demonstrações financeiras); Instrução CVM 457/2007 (determinou a adoção do IFRS para a elaboração de demonstrações financeiras). Para a reconstrução das reformas sobre o regime jurídico de disclosure no mercado de valores mobiliários brasileiro e a demonstração da sua importância para a modernização do nosso sistema, ver: PITTA, André Grünspun. O Regime de Informação das Companhias Abertas. 1a edição. Quartier Latin: São Paulo, 2013, p. 183-261.
} 
do quadro regulatório brasileiro ${ }^{3}$. Apesar de não ser possível, por sua singularidade, elaborar conclusões generalizantes da análise desse caso, há potencial em seu estudo para trazer elementos para refletir sobre as seguintes perguntas ${ }^{4}$ : (i) Quando grupos de interesses vão ao Poder Judiciário? (ii) Como eles acessam o Poder Judiciário? e (iii) Qual é o impacto da litigância envolvendo as agências reguladoras (direta ou indiretamente) na regulação e no quadro regulatório?

Além disso, o caso nos fornece informações relevantes sobre como é vista pelo Judiciário a modernização na estrutura regulatória do mercado de capitais, com a importação de padrões internacionais - em especial, quando há direitos individuais envolvidos ${ }^{5}$.

Este estudo está dividido em quatro partes. A primeira identifica o campo normativo da CVM e a sua atuação na criação de normas nos últimos anos, bem como a influência internacional na sua atividade normativa. A segunda trata da relação entre CVM e Poder Judiciário. A terceira analisa o caso da interferência do Judiciário na exigência da CVM para maior transparência da remuneração dos administradores de companhias abertas. Ao final, são apresentadas as conclusões que apontam que o Poder Judiciário não é usualmente chamado a opinar sobre a atividade normativa da CVM. O caso estudado demonstrou o potencial que existe por trás do seu poder de controle: a possibilidade da sua utilização para a manutenção do status quo no caminho evolutivo do nosso sistema regulatório do mercado de valores mobiliários.

\section{A COMISSÃo DE VALORES MOBILIÁRIOS E O SEU PAPEL REGULADOR NO NOVO CENÁRIO DO MERCADO DE CAPITAIS BRASILEIRO}

A partir de 2004 houve crescimento significativo do mercado acionário como forma de financiamento da atividade produtiva no Brasil. A captação de recursos pelas empresas brasileiras via emissão de ações aumentou consideravelmente, como mostram os números sobre o volume de ofertas públicas registradas na CVM e colocadas para negociação na BM\&FBovespa. Em 2004, o volume da captação foi de R \$ 8,8 bilhões. Em 2007, as ofertas públicas somaram R \$ 70,1 bilhões. Em 2008, apesar da crise financeira mundial, o valor de captação chegou a R\$ 34,3 bilhões; e, em

\footnotetext{
${ }^{3}$ O questionamento da Instrução CVM 308/99, que determinou o rodízio do Auditor Independente, é outro caso relevante, apesar de referir-se à regulação da CVM anterior aos anos 2000. Os demais questionamentos no Judiciário acerca da atividade normativa referem-se à cobrança de taxas impostas pela CVM aos agentes do mercado de valores mobiliários. Entendo que esta cobrança não é relevante para fins de verificar a participação do Poder Judiciário no núcleo duro da atividade de criação de normas da CVM que regulam condutas destes agentes.

${ }^{4}$ Essas perguntas foram formuladas no projeto de pesquisa denominado "Regulatory State of the South", coordenado pelos professores Rene Urueña e Mariana Mota Prado.

5 Sobre o papel do Judiciário na importação de modelos regulatórios internacionais, ver: DUBASH, Navroz K.; MORGAN, Bronwen. Understanding the rise of the regulatory state of the South. In: Regulation \& Governance, 6, 2012, p. 261-281, e URUEÑA, Rene. The rise of the constitutional regulatory state in Colombia: the case of water governance. In: Regulation \& Governance, 6, 2012, p. 282-299.
} 
2009, totalizou R \$ 46 bilhões. Em 2010, R\$ 74,4 bilhões, havendo queda em 2011 (R 18 bilhões) e 2012 (R\$ 13 bilhões) ${ }^{6}$. Desde 2013 a captação no mercado de ações deixou de ser um veículo importante para o financiamento das empresas brasileiras. Apesar da redução do volume de captação, outra métrica interessante capaz de demonstrar a relevância do mercado de ações é a média do volume de negociação diário em 2004, que atingiu R\$ 1,2 bilhão, tendo ficado, nos últimos anos, em R\$ 7,4 bilhões (2013), R\$ 7,3 bilhões (2014) e R\$ 6,7 bilhões (até agosto de $2015)^{7}$.

Nestes quase 10 anos de crescimento do mercado acionário brasileiro, os investidores estrangeiros tiveram participação crucial, em especial, nas ofertas públicas iniciais de ações (IPO, na sigla em inglês). Em 2009, eles representaram 66,7\% dos investidores participantes; em 2008, 65,6\%; em 2007, 72,3\%; em 2006, 72,8\%; em 2005, 61,7\%; e em 2004, 69,7\% ${ }^{8}$. Sem os estrangeiros, as captações não seriam tão vultosas. Quanto ao volume negociado no mercado secundário, a participação dos investidores internacionais gira em torno de 35\% desde 2005, chegando a 52\% em 2015 (até o mês de agosto) ${ }^{9}$.

Neste mesmo período, os investidores institucionais nacionais, por sua vez, representaram aproximadamente entre $26 \%$ e $35 \%$ do volume negociado ${ }^{10}$. No mercado secundário, investidores estrangeiros e institucionais nacionais somaram, em 2012, 70\% do volume de negociação diário. A forte participação desses investidores institucionais na BM\&FBovespa começou no início dos anos 90 e se mantém até os dias atuais ${ }^{11}$. Em suma, o crescimento recente do mercado de ações brasileiro foi dependente da grande participação de investidores estrangeiros e institucionais nacionais.

Esses investidores qualificados, por terem grande poder econômico e de decisão de investimento e desinvestimento, conseguiram impulsionar o aperfeiçoamento do quadro regulatório brasileiro. Mas essa influência não se deu por meio de ações de lobby desses investidores no processo legislativo. Ocorreu a partir de iniciativas de agentes locais interessados em atrair tais

\footnotetext{
${ }^{6}$ Cf. BMF\&BOVESPA. Bolsa de Valores de São Paulo. Relatório Anual - 2012. p. 77. Disponível em: $<$ http://goo.gl/U7zTsk>. Acesso em: 14 jun. 2015.

${ }^{7}$ Dados sobre a média diária de negociação nas estatísticas da bolsa estão disponíveis em: <http://goo.gl/0c3Cyo>, p. 24. Acesso em: 14 jun. 2015.

${ }^{8}$ Dados retirados de CREDIT SUISSE. A guide to the Brazilian economy - 2009. 11 set. 2009. Disponível em: <http://www.credit-suisse.com/researchandanalytics>. Acesso em: 14 jun. 2015.

${ }^{9}$ Números verificáveis no Relatório Anual 2010 da BM\&FBovespa, p. 41, disponível em: <http://goo.gl/pk522l>, e nas estatísticas da BM\&FBovespa, p. 26, disponíveis em: <http://goo.gl/0c3Cyo>.

10 Ibid., loc. cit.

${ }^{11}$ MATTOS FILHO, Ary Oswaldo; PRADO, Viviane Muller. Tentativas de desenvolvimento do mercado acionário brasileiro desde 1964. In: PADUA LIMA, Maria Lúcia L. M. Agenda contemporânea. Direito e economia: 30 anos de Brasil, tomo 2. São Paulo: Saraiva, 2012, p. 211-217.
} 
investidores para fomentar o mercado. Um dos pontos sensíveis para atingir esse objetivo era o aperfeiçoamento da regulação do mercado de valores mobiliários ${ }^{12}$.

O pontapé das reformas deu-se com a criação de níveis diferenciados de governança corporativa, que poderiam ser adotados voluntariamente pelas empresas. Optou-se pela regulação privada diante da impossibilidade de modificação da legislação com vistas à adoção de padrões internacionalmente aceitos de governança corporativa ${ }^{13}$. A adesão às novas regras da Bolsa não se aplicou a todas as companhias brasileiras, mas somente àquelas que aderiram voluntariamente aos regulamentos de listagem de ações da BM\&FBovespa em três modalidades: Novo Mercado, Nível 1 ou Nível 2. À regulação privada seguiram-se regras relevantes desenhadas e implementadas pela CVM e, ainda, por reformas nas leis das sociedades por ações e de mercado de capitais ${ }^{14}$. Um dos principais temas da reforma estatal dizia respeito ao campo de aperfeiçoamento do regime informacional (full disclosure).

Parte destas reformas ocorreu com a atuação da CVM, que é a autarquia em regime especial $^{15}$ competente para regular, supervisionar, fiscalizar e punir os agentes que atuam no mercado de valores mobiliários brasileiro. Segundo a lei de criação da CVM, o principal objetivo é proteger os investidores, assegurar o funcionamento eficiente dos mercados e fomentar a formação de poupança e investimento no mercado de valores mobiliários ${ }^{16}$. A CVM teve sua competência ampliada ao longo dos mais de 30 anos de sua existência. Atualmente, regula os mercados de ações, debêntures, quotas de fundos de investimentos em valores mobiliários, commercial papers, derivativos e contratos ou títulos de investimento coletivos ${ }^{17}$.

A atividade regulatória da CVM foi particularmente intensa nos últimos dez anos. No

\footnotetext{
${ }^{12}$ Cf. BMF\&BOVESPA. Bolsa de Valores de São Paulo. Estudos para o Desenvolvimento do Mercado de Capitais. Desafios e oportunidades para o mercado de capitais brasileiro. Junho de 2010. Disponível em: <https://goo.gl/CMSy6C>. Acesso em: 14 jun. 2015, e SANTANA, Maria Helena et al. Novo Mercado and its Followers: Case Studies in Corporate Governance Reform. Global Corporate Governance Forum, 2008. Disponível em: <http://goo.gl/3nsbcb>. Acesso em: 14 jun. 2015.

${ }^{13}$ Cf. GILSON, Ronald J.; HANSMANN, Henry; PARGENDLER, Mariana. Regulatory Dualism as a development strategy: corporate reform in Brazil, the United States, and the European Union. In: Stanford Law Review, vol. 63, March/2001, n. 3, p. 475-537. Os autores encontram no dualismo regulatório a alternativa para reformas quando não se mostra viável pensar em mudanças na legislação. O Brasil aparece como um caso de dualismo regulatório.

14 Mencione-se a importância da Lei 11.368/2007, que reformou a disciplina das demonstrações financeiras das companhias abertas e sociedades de grande porte. Mediante essa legislação, adotaram-se no Brasil os padrões internacionais de demonstrações contábeis.

${ }^{15}$ A CVM foi criada pela Lei 6.385/1976, com o intuito de ser uma autarquia especializada na regulação do mercado de valores mobiliários, sucedendo o Banco Central do Brasil. Sua criação foi fortemente inspirada na Securites and Exchange Commission norte-americana. No campo da estrutura regulatória, as Leis 10.303/2001 e 10.411/2002 conferiram mais autonomia administrativa à CVM como instituição reguladora e fiscalizadora do mercado de valores mobiliários, aproximando-a da figura das agências reguladoras criadas a partir de privatizações em vários mercados.

${ }^{16}$ Atribuições explicitadas no art. $4^{\circ}$ da Lei 6.385/1976 (Lei de Mercado de Capitais).

${ }^{17}$ Exclui-se da competência da CVM os títulos emitidos pelo poder público e também os títulos de responsabilidade de instituições financeiras (art. $2^{\circ}$ da Lei 6.385/1976).
} 
mercado de ações, teve e tem papel bastante importante na modernização do quadro regulatório atual, ao elaborar instruções normativas relevantes. Entre outros temas, reelaborou o regramento sobre a apresentação de informações a serem divulgadas pelas companhias emissoras, aproximando-o de padrões internacionais (Instrução CVM 480/2009); simplificou a emissão de valores mobiliários com esforços restritos (Instrução CVM 471/2008); adotou o padrão contábil internacional emitido pelo IASB (International Accounting Standards Board) (Instrução CVM 457/2007); disciplinou os vários tipos de oferta pública de aquisição de ações (Instrução CVM 361/2002); tratou da organização das bolsas, possibilitando transformação dessas em empresas e revisitando as questões da competência regulatória dos mercados organizados e sua relação com a CVM (Instruções CVM 461/2007 e 468/2008) e regulou empresas de classificação de risco (Instrução CVM 521/2012). Em 2014, ano relevante para a nova disciplina dos fundos de investimento, foi expedida a Instrução CVM 555, e, em 2015, houve a edição de novas regras para as reorganizações societárias (Instrução CVM 565/2015).

Várias destas regras administrativas encontram forte inspiração em padrões regulatórios internacionais ou em normas existentes em outros sistemas jurídicos ${ }^{18}$. Nos relatórios das audiências públicas da CVM, muitas vezes encontram-se referências aos princípios da IOSCO (International Organization of Securities Commissions), aos normativos da SEC (Securities and Exchange Commission norte-americana) e do Parlamento europeu, como é o caso da Markets in Financial Instruments Directive (MiFID), seja para explicar a origem e o conteúdo da nova norma, seja para justificar a importância da sua adoção.

Além da identificação da influência do padrão regulatório internacional, a CVM passa a ter importante participação nos foros internacionais. Em relação à IOSCO, é membro fundador e ordinário, em 2009 foi admitida como membro do Comitê Técnico ${ }^{19}$ e atualmente também compõe o Comitê de Mercados Emergentes e Comitê Executivo da instituição. De 2011 a 2012, a então presidente da CVM, Maria Helena Santana, presidiu o Comitê Executivo. A CVM também é membro do Inter-American Committee e de grupos de trabalho responsáveis pelo aperfeiçoamento

\footnotetext{
${ }^{18}$ Para a demonstração da influência dos padrões regulatórios internacionais na atividade regulatória da CVM, ver: RACHMAN, Nora; PRADO, Viviane Muller; COELHO, Alexandre. Internalização dos padrões regulatórios no Brasil: o caso IOSCO. 2015. No prelo.

19 Além disto, a BM\&FBovespa, a BM\&FBovespa Supervisão de Mercado - BSM, a Associação Brasileira das Entidades dos Mercados Financeiro e de Capitais (ANBIMA) e a CETIP são membros do Comitê Consultivo da IOSCO, juntamente com outras entidades autorreguladoras.
} 
na regulação dos fundos de investimento, além de participar do Financial Stability Board (FSB), em um dos três assentos destinados ao Brasil ${ }^{20}$.

Em suma, recentemente os investidores estrangeiros e institucionais passaram a ser os atores que fazem girar a roda do mercado de capitais brasileiro. Na parte regulatória, o Brasil participa do processo global de convergência regulatória, tanto com a adoção de padrões internacionais às novas regras da CVM quanto com a sua participação em foros internacionais. Entretanto, apesar de importante parte das reformas corresponder à internalização de regras sugeridas nos foros internacionais, dos quais a CVM participa, as eventuais disputas sobre essas regras são administradas pelo Poder Judiciário nacional, como se discutirá a seguir.

\section{PARTICIPAÇÃO DO PODER JUDICIÁRIO NA REGULAÇÃO DO MERCADO DE CAPITAIS BRASILEIRO}

No Brasil, o Poder Judiciário é a última instância decisória com competência para fiscalizar a atividade das agências reguladoras e, portanto, a atividade da CVM ${ }^{21}$. Essa competência de revisão a posteriori existe tanto sobre a atividade de criação de regras quanto de fiscalização e punição pela CVM.

A relação entre a CVM e o Poder Judiciário já foi objeto de pesquisa quantitativa realizada em 2010 para o Conselho Nacional de Justiça $(\mathrm{CNJ})^{22}$. O objeto do estudo foram as inter-relações entre o processo administrativo e o judicial a partir da análise de doze agências reguladoras brasileiras, entre elas a $\mathrm{CVM}^{23}$. Os resultados apontaram alta judicialização da atividade regulatória da CVM. Ela apareceu como a segunda agência reguladora no Brasil cujas decisões são levadas com maior frequência para a apreciação do Poder Judiciário, perdendo apenas para a Agência Nacional de Telecomunicações (ANATEL). Segundo esse levantamento, à época da pesquisa (2010) havia 22.136 processos judiciais envolvendo a autarquia nas primeiras instâncias da Justiça Federal.

\footnotetext{
${ }^{20}$ Para saber mais sobre a atuação do Brasil em foros regulatórios internacionais, cf. COMISSÃO DE VALORES MOBILIÁRIOS. Relatório Anual 2011. Disponível em: <http://goo.gl/lPsyvi>. Acesso em: 14 jun. 2015.

21 “A lei não excluirá da apreciação do Poder Judiciário lesão ou ameaça a direito”. BRASIL. Constituição da República Federativa do Brasil de 1988. Diário Oficial da União, Brasília, 5 de outubro de 1988, artigo 5º inciso XXXV.

${ }^{22}$ Cf. FERRAZ JUNIOR, Tércio Sampaio; MARANHÃO, Juliano Souza de Albuquerque; AZEVEDO, Paulo Furquim de. Inter-relações entre o processo administrativo e o judicial sob a perspectiva da segurança jurídica no plano da concorrência econômica e da eficácia da regulação pública. 2010. Disponível em: $<$ http://www.niajajuris.org.br/images/documentos/rfusp.pdf>. Acesso em: 14 jun. 2015.

${ }^{23}$ As doze agências reguladoras estudadas foram: ANAC, ANATEL, ANEEL, ANP, ANS, ANTT, ANVISA, CVM, ANA, ANCINE, ANTAQ e PREVIC.
} 
O resultado desse estudo foi considerado bastante contraintuitivo por aqueles que trabalham no mercado de valores mobiliários e acompanham a atividade regulatória da CVM. A razão para a estranheza é que, ao contrário do que sugeriam os números levantados pela pesquisa, a atividade regulatória da CVM parece não ser objeto de questionamento constante no Judiciário.

Ao revisitar os dados e a metodologia do estudo, é possível entender os altos números encontrados quanto à judicialização da CVM e explicar por que os mesmos causaram estranheza. Os casos analisados não eram relacionados à principal atividade regulatória da CVM e ao cumprimento do seu papel na regulação do mercado de valores mobiliários. Todos os casos da amostra referem-se a um único tema: cobrança de taxa de fiscalização. Em geral, trata-se de taxa a ser paga, nos termos da Lei 7.940/89, pelas pessoas físicas e jurídicas que integram o sistema de distribuição de valores mobiliários, as companhias abertas, fundos e sociedades de investimento, administradores de carteira e depósito, consultores e analistas, agentes autônomos, auditores independentes e sociedades beneficiárias de incentivos fiscais obrigadas a registro na $\mathrm{CVM}^{24}$. Este tema já foi muito questionado e debatido no Judiciário, levando o Supremo Tribunal Federal, em 2003, a editar a Súmula 665, expondo o entendimento de que “É constitucional a taxa de fiscalização dos mercados de títulos e valores mobiliários instituída pela Lei 7.940/1989”.

Em resumo, a matéria discutida nos casos levantados não tem ligação com as normas que disciplinam a atuação e conduta dos agentes do mercado de capitais e nem como a atividade punitiva da CVM. Trata-se de mera cobrança de tributo. Estes casos poderiam ter sido classificados como não pertinentes, conforme os critérios expostos no relatório ${ }^{25}$, pois não decorrem “da contestação de decisão regulatória”. Com essa mudança de classificação, e assumindo que a amostra é representativa da totalidade dos casos judicializados, seria possível concluir que não há participação relevante do Poder Judiciário na regulação do mercado de valores mobiliários ${ }^{26}$.

Além deste estudo ainda não existe, no Brasil, outra pesquisa empírica sobre o real papel do Poder Judiciário na regulação do mercado de valores mobiliários brasileiro. Nos últimos dez anos (ou seja, dentro do período de intensas reformas) o caso aqui discutido parece ter sido o único no qual se questionou uma norma da CVM perante o Judiciário no Brasil. Isso considerado, o

\footnotetext{
${ }^{24}$ Cf. BRASIL. Lei n ${ }^{\circ}$ 7.940, de 20 de dezembro de 1989. Institui a Taxa de Fiscalização dos mercados de títulos e valores mobiliários, e dá outras providências. Diário Oficial da União, Brasília, 21 de dezembro de 1989, artigo 3º.

${ }^{25}$ Cf. Cf. FERRAZ JUNIOR, Tércio Sampaio; MARANHÃO, Juliano Souza de Albuquerque; AZEVEDO, Paulo Furquim de, op. cit., p. 117.

${ }^{26}$ Os números mais altos de judicialização apareceram em estados pouco representativos para o mercado de valores mobiliários (Amazonas, Goiás, Maranhão, entre outros), enquanto não há nenhum caso no estado do Rio de Janeiro, onde está sediada a CVM. Esses números sugerem o questionamento sobre se o sistema de busca do site dos tribunais federais é adequado para a realização de pesquisa de jurisprudência pretendida.
} 
objetivo deste estudo é analisar qualitativamente se e como o Poder Judiciário participa nesta nova era regulatória da CVM, a qual está em conexão com a internalização dos padrões internacionais para a regulação do mercado de valores mobiliários.

\section{ANÁLISE DO CASO DA TRANSPARÊNCIA DA REMUNERAÇÃo DOS ADMINISTRADORES}

O estudo de um único caso encontra controvérsias sobre a sua validade e relevância para a produção de conhecimentos ${ }^{27}$.

A metodologia é defendida quando a intenção da pesquisa é aprender com as particularidades e detalhes de um único caso, sem pretender conclusões gerais ou a demonstração do potencial repetitivo do caso estudado ${ }^{28}$. A ênfase do estudo do caso único está na interpretação dos fatos ${ }^{29}$, considerando a sua complexidade ${ }^{30}$.

Neste texto, a escolha para análise encontra justificativa por se tratar do único caso no qual particulares questionaram o poder regulatório da CVM nos últimos 10 anos. Não se trata, portanto, de exemplo escolhido aleatoriamente. Não se trata também de análise de decisão judicial ou jurisprudência sobre um tema.

O interesse no estudo do questionamento da transparência da remuneração dos administradores está na análise de todos os seus detalhes e na cadeia de fatos, desde a concepção da regulação do tema em foros internacionais até os efeitos da decisão liminar no sentido de não obrigar à divulgação dos salários. A partir da pesquisa, foi possível juntar informação sobre (i) o mercado de valores mobiliários brasileiro, verificando-se o seu crescimento e a indispensável

\footnotetext{
${ }^{27}$ Para uma síntese do debate sobre o estudo de caso único, ver (apesar de a reflexão ser em pesquisa em administração, os pontos trazidos são relevantes para pensar na pesquisa jurídica): MARIOTTO, Fabio Luiz; ZANNI, Pedro Pinto; MORAES, Gustavo Hermínio Salati Marcondes de. What is the use of a single-case study in management research? Revista de Administração de Empresas, vol. 54, ano 4, São Paulo, julho/agosto 2014. Disponível em: <http://goo.gl/B9tBF4>. Acesso em: 6 fev. 2016. Sobre a utilização do método em um caso de pesquisa jurídica, ver: GHIRARDI, José Garcez; PALMA, Juliana Bonacorsi de; VIANA, Manuela Trindade. Posso fazer um trabalho inteiro sobre um caso específico? In: QUEIROZ, Rafael Mafei Rabelo; FEFERBAUM, Marina. Metodologia jurídica: um roteiro prático para trabalhos de conclusão de curso. São Paulo: Saraiva, 2012, p. 178-190, e MACHADO, Maíra Rocha. Contra a departamentalização do saber jurídico: a contribuição dos estudos de caso para o campo direito e desenvolvimento. In: SILVEIRA, Vladmir Oliveira da; SANCHES, Sandra Naspolini; COUTO, Monica Bonetti. Desenvolvimento nas ciências sociais. O estado das artes. Direito e desenvolvimento no Brasil do século XXI. Brasília: Ipea, Conpedi, 2013, p. 177-200. Disponível em: <http://goo.gl/UkgGJ1>. Acesso em: 6 fev. 2016.

${ }^{28}$ Nesse sentido, ver: MORICEAU, Jean-Luc. What can we learn from a singular case like Enron? Critical Perspective on Accounting, n. 16, Elsevier, 2005, p. 794, e STAKE, Robert E. The art of case study research. London: Sage, 1995 (esse autor dedica um capítulo à defesa da análise de um único caso. Afirma que: "The real business of case study is particularization, not generalization).

${ }^{29}$ STAKE, Robert E., op. cit., indica, à página 8, que se deve dar ênfase à interpretação.

${ }^{30}$ Aqui está a justificativa de Yin para a realização do estudo de caso. Trata-se do "desejo de compreender fenômenos sociais complexos” (YIN, Robert K. Estudo de caso. Planejamento e métodos. Porto Alegre: Bookman, 2005, p. 20).
} 
participação dos investidores estrangeiros e institucionais; (ii) a volumosa atividade regulatória da CVM, com algumas normas inspiradas em regras defendidas em foros internacionais; (iii) a modificação da norma internacional para acomodar os interesses de atores brasileiros, após manifestações em audiência publica da CVM; (iv) os argumentos trazidos por executivos de companhias abertas questionando o poder normativo da CVM que exige a divulgação da remuneração dos administradores, sendo uma ação ajuizada individualmente e outra por meio de uma associação, bem como os contra-argumentos da CVM; (v) os fundamentos das decisões judiciais nas várias instâncias, tanto em fase liminar como em fase final; e, por fim, (vi) o surpreendente comportamento de algumas companhias que se beneficiam da decisão judicial em não utilizar a liminar e a resposta do mercado em algumas assembleias gerais. É nesse conjunto de informações que se buscam elementos para responder às perguntas de pesquisa acima colocadas, sobre o papel do Poder Judiciário na regulação do mercado de capitais brasileiro. Ressalta-se que não se pretende afirmar como ele atua ou deve atuar, mas trazer elementos, a partir do caso, para refletir sobre sua potencialidade, a razão de ter sido chamado a se pronunciar e os efeitos da decisão judicial.

Sabe-se que nenhuma metodologia é perfeita, mas, para trazer pistas sobre o funcionamento do nosso sistema, a leitura do mercado sobre a decisão judicial e a atuação de um agente local (Judiciário) que não participa dos foros internacionais, a análise do único caso parece ser adequado método de pesquisa ${ }^{31}$.

\subsection{O TEMA}

O caso versa sobre o questionamento no Poder Judiciário de norma da CVM que determina a divulgação pública da remuneração dos administradores das companhias abertas. Trata-se de ação judicial proposta pelo Instituto Brasileiro de Executivos - IBEF, associação civil sem fins lucrativos com sede no Rio de Janeiro, que congrega companhias abertas e seus administradores.

Como sugere a pesquisa quantitativa referida acima, não é usual o questionamento dos atos normativos da CVM no Poder Judiciário, salvo para o não pagamento de tributo. O caso em análise parece ser o único a contestar a atividade normativa da CVM desde os anos 2000. Isso levanta uma

\footnotetext{
${ }^{31}$ MILHAUPT, Curtis J.; PISTOR, Katharina. Law \& Capitalism: What corporate Crises reveal about legal systems and economic development around the world. Chicago: University of Chicago Press, 2008. Os autores utilizaram no livro a metodologia do estudo de casos em diversos países, e advertem: "No methodology is perfect, and we want to adress the limitations o fours up front” (p. 10). Observam ainda o objetivo "learn from the autopsy about a system” (p. 11).
} 
questão bastante relevante: o que ocorreu para que uma associação representativa de executivos de grandes companhias abertas buscasse o amparo do Poder Judiciário para proteger os seus direitos? A resposta está relacionada com o interesse que a norma atinge: o interesse particular dos administradores. A norma determina a publicidade dos valores dos seus salários. Ou seja, essa regulação possui uma particularidade: afeta direitos individuais - no caso, o alegado direito à privacidade. Isso poderia explicar por que os atores interessados recorreram ao Judiciário. O caso em análise levanta questão interessante sobre como o Poder Judiciário se posiciona na contraposição de direitos individuais e da regulação do mercado de valores mobiliários que justamente pretende aperfeiçoar as regras de governança corporativa brasileiras, com forte inspiração em padrões internacionais.

\subsection{O DEBATE INTERNACIONAL SOBRE TRANSPARÊNCIA DA REMUNERAÇÃO DOS ADMINISTRADORES}

Com a crise financeira internacional de 2008, a adequação da remuneração dos administradores tornou-se ponto de inquestionável importância, para compreensão da origem da crise, nas instituições financeiras ${ }^{32}$.

A regulação internacional sobre o tema da adequação e transparência dos critérios e valores da remuneração dos administradores iniciou-se no Financial Stability Board (FSB). Em 2008, o Financial Stability Forum (FSF) recomendou que “reguladores e supervisores atuassem junto com os participantes do mercado para mitigar os riscos originários das políticas de remuneração"33.

No ano seguinte, o FSB tornou público o seu Principles for Sound Compensation Practices $^{34}$, cujo objetivo é "garantir uma governança efetiva de compensação, alinhando-a com a prudência na tomada de risco e na supervisão efetiva e o engajamento de terceitos afetados no desenvolvimento da atividade (stakeholder).”35 Entre medidas sugeridas para conhecer a relação

\footnotetext{
${ }^{32}$ Cf. BEBCHUK, Lucian A.; COHEN, Alma; SPAMANN, Holger. The wages of failure: executive compensation at Bear Stearns and Lehman 2000-2008. Yale Journal on Regulation, vol. 27, 2010, p. 257-282. Disponível em: <http://papers.ssrn.com/sol3/papers.cfm?abstract_id=1513522>. Acesso em: 14 jun. 2015.

${ }^{33}$ Formou-se um Compensation Workstream Group ao qual foi atribuída a tarefa de elaborar "draft sound practice principles for large financial institutions”.

${ }^{34}$ Cf. FINANCIAL STABILITY FORUM. FSF Principles for Sound Compensation Practices. 2 April 2009. Disponível em: <http://goo.gl/t7Lxnx>. Acesso em: 14 jun. 2015.

35 O FSB ainda complementa, sobre a implantação dos princípios: “The benefits of sound compensation practices will be achieved only if there is determined and coordinated action by national regulators, facilitated if necessary by suitable legislative powers and supported by national governments” (Item I).
} 
entre remuneração e risco das companhias, o documento orienta a publicação das remunerações para a possível fiscalização pelos stakeholders; em especial, pelos acionistas ${ }^{36}$.

Na IOSCO, entidade que reúne os reguladores do mercado de valores mobiliários, por sua vez, recomendava-se, nas versões dos Objectives and Principles of Securities Regulation desde 1998, apenas a transparência financeira total, ao investidor, de todos os dados que pudessem afetar a sua decisão de investimento. Até 2010 não havia documento, entretanto, que sugerisse especificamente a ampla abertura da remuneração dos administradores de companhias abertas.

Em fevereiro de 2010, a IOSCO publicou documento novo, denominado Principles for Periodic Disclosure by Listed Entities ${ }^{37}$. Conforme esses princípios, entre as informações relevantes que devem ser dadas por empresas listadas estão os dados sobre a remuneração dos administradores. Esses dados são considerados relevantes para o investidor avaliar os incentivos criados a partir de tal uso dos seus recursos, bem como avaliar se tais incentivos estão alinhados com os interesses do investidor ${ }^{38}$.

\subsection{O DEBATE NACIONAL SOBRE TRANSPARÊNCIA DA REMUNERAÇÃO DOS ADMINISTRADORES E AS NOVAS NORMAS DA CVM}

A legislação acionária brasileira exigiu desde 1976 que anualmente fosse deliberada a remuneração dos administradores em assembleia geral ordinária ${ }^{39}$, que “fixará o montante global ou individual dos administradores, inclusive benefícios de qualquer natureza e verbas de representação, tendo em conta suas responsabilidades, o tempo dedicado às suas funções, sua competência e reputação profissional e o valor dos seus serviços no mercado" 40 . Na prática, as deliberações eram quanto ao montante global, isto é, o valor gasto com toda a estrutura administrativa, tanto para membros do conselho de administração quanto para diretores. Como se pode perceber, não havia nenhuma exigência de divulgar como o bolo era dividido, quais eram os montantes fixos e quais os valores variáveis.

\footnotetext{
${ }^{36} \mathrm{Na}$ redação literal: "Principle 9. Firms must disclose clear, comprehensive and timely information about their compensation practices to facilitate constructive engagement by all stakeholders. Stakeholders need to be able to evaluate the quality of support for the firm's strategy and risk posture. Appropriate disclosure related to risk management and other control systems will enable a firm's counterparties to make informed decisions about their business relations with the firm. [...]”

${ }^{37}$ Cf. IOSCO. Principles for Periodic Disclosure by Listed Entities - Final Report, February 2010. Disponível em: $<$ http://goo.gl/hYhUXu>. Acesso em: 14 jun. 2015.

${ }^{38}$ Vide Letra d: Compensation disclosure.

${ }^{39}$ Cf. BRASIL. Lei $\mathrm{n}^{\circ}$ 6.404, de 15 de dezembro de 1976. Dispõe sobre as Sociedades por Ações. Diário Oficial da União, Brasília, 17 de dezembro de 1976, artigo 132.

${ }^{40}$ Cf. Cf. BRASIL. Lei $n^{\circ}$ 6.404, de 15 de dezembro de 1976. Dispõe sobre as Sociedades por Ações. Diário Oficial da União, Brasília, 17 de dezembro de 1976, artigo 152.
} 
Em 2008, mesma época da discussão do tema no FSF/FSB, a CVM colocou em audiência pública projeto de regulamentação administrativa que tornava mais rigorosas as regras sobre informações dadas ao mercado por companhias abertas (Edital de Audiência Pública n. 07/200841). Um dos itens dessa regulamentação tratava da divulgação de dados sobre remuneração dos administradores, nos moldes da regulação discutida em foros internacionais.

A proposta inicial era a divulgação individual da remuneração de cada administrador ${ }^{42}$. No curso da audiência pública, houve um total de 33 manifestações sobre as novas regras de remuneração dos administradores, sendo que sete foram favoráveis à divulgação individual da remuneração e 24 contrárias. Entre as 24 manifestações contrárias, 15 foram favoráveis à divulgação, mas de forma não individualizada, por órgão da administração ${ }^{43}$. Nessas, houve quem argumentasse que a divulgação individual, em tese, seria boa para o mercado de valores mobiliários, mas que ainda não era o momento de o Brasil adotar tal padrão de transparência, pois ela traria mais ônus que benefícios. Tais ônus estariam ligados a questões culturais ${ }^{44}$, concorrência desigual com sociedades de capital fechado e preocupações com segurança, dados os índices de violência no País ${ }^{45}$. Além disso, alguns argumentaram que a obrigação de divulgação da remuneração individualizada violaria o direito fundamental à intimidade e à vida privada, garantido pelo art. $5^{\circ}$ da Constituição Federal.

Em resposta às criticas feitas pelos participantes na audiência pública, e para justificar a nova regra, a CVM fez expressa referência às melhores práticas internacionais ${ }^{46}$. Sobre a

\footnotetext{
${ }^{41}$ Cf. COMISSÃO DE VALORES MOBILIÁRIOS. Relatório de Análise da Superintendência de Desenvolvimento do mercado (SDM) à audiência pública n. 07/2008. 7 dez. 2009. Disponível em: <http://goo.gl/C6U5tp>. Acesso em: 14 jun. 2015. Ressalta-se que nesta minuta a CVM faz expressa referência ao modelo, sugerido pela IOSCO, de "self registration system” (Adapting IOSCO International Disclosure Standards for Self Registration System, março de 2001).

${ }^{42}$ No projeto colocado para audiência pública, a CVM indicava que gostaria de saber do mercado sobre a "conveniência e necessidade de se exigir que informações sobre a remuneração de administradores fossem prestadas de maneira individualizada (por administrador) ou por órgão da administração” (Item 11.8).

${ }^{43}$ Dados apontados no Relatório de Análise da Superintendência de Desenvolvimento do mercado (SDM) à audiência pública 07/2008.

44 É interessante ler o argumento a ser refutado pela CVM, no Item 11.8. Cf. COMISSÃO DE VALORES MOBILIÁRIOS. Relatório de Análise da Superintendência de Desenvolvimento do mercado (SDM) à audiência pública $n$. 07/2008. 7 dez. 2009. Disponível em: <http://goo.gl/C6U5tp>. Acesso em: 14 jun. 2015, p. 52-53. Sobre o aspecto cultural, cf. TANOUE, Luciana. O tabu da remuneração. Os aspectos culturais, sociológicos e psicológicos que explicam a recusa dos administradores de companhias abertas em ter sua remuneração revelada. In: Capital Aberto, Ano 7, n. 80, abril/2010, p. 32-36.

45 “Por fim, há o argumento da segurança. Há os que acreditem que, em um país com os índices de violência encontrados no Brasil, é temerária a ampla divulgação de informações sobre a remuneração individual de administradores” (Item 11.8).

46 “As melhores práticas internacionais ditam que se deve buscar nível elevado de transparência nas informações sobre remuneração e programas de incentivos dos administradores (Corporate Governance in Emerging Markets - Report from Emerging Markets Committee of the IOSCO, Dezembro de 2007)" Cf. COMISSÃO DE VALORES MOBILIÁRIOS. Relatório de Análise da Superintendência de Desenvolvimento do mercado (SDM) à audiência pública n. 07/2008. 7 dez. 2009. Disponível em: <http://goo.gl/C6U5tp>. Acesso em: 14 jun. 2015, p. 58.
} 
importância da transparência da remuneração individual, a autarquia citou países que adotam essa regra - França, África do Sul e Estados Unidos - e propôs o avanço gradativo deste ponto na regulação brasileira ${ }^{47}$. A resistência, todavia, persistiu.

Por fim, a CVM decidiu-se pelo caminho do meio. A nova regra passou a exigir que se divulgue a política de remuneração dos administradores, informando a composição da remuneração, os objetivos de cada um dos seus elementos e as razões que justificam a composição da remuneração, para que ela seja apta a refletir a evolução dos indicadores de desempenho escolhidos e possa indicar se tal política se alinha à perspectiva de resultados de curto, médio e longo prazo. Além disso, exige a divulgação em relação a cada órgão da administração (mas sem identificar o que cabe a cada administrador individualmente), indicando os valores maior, menor e médio das remunerações pagas aos membros de cada órgão ${ }^{48}$. Para justificar a nova regra, CVM deu a seguinte declaração: “A CVM está certa de que este nível de transparência vai induzir o mercado a um debate sobre as políticas de remuneração, bem como suprir investidores com subsídios necessários para formularem questionamentos a emissores que adotem práticas menos sólidas que as desejáveis. Este debate será saudável e tende a melhorar as práticas de remuneração"49.

Além do debate em foros empresariais e acadêmicos, um novo ator foi chamado para discutir a nova regra de governança corporativa no Brasil: o Poder Judiciário.

\subsection{PODER JUDICIÁRIO NA DISPUTA SOBRE A NOVA REGRA DA CVM QUANTO À TRANSPARÊNCIA DA REMUNERAÇÃO DOS ADMINISTRADORES}

O Judiciário foi acionado duas vezes para decidir sobre a constitucionalidade e a validade da exigência trazida pelas novas regras da CVM quanto à publicação dos valores da remuneração dos administradores. Uma ação foi ajuizada pelo IBEF - Instituto Brasileiro de Executivos de Finanças - do Rio de Janeiro, a qual ainda aguarda julgamento final. Em outro caso, uma empresa

\footnotetext{
47 “Alcançar os padrões internacionais de transparência, inclusive em relação à divulgação da remuneração dos administradores, é processo inexorável para qualquer país que deseje desenvolver um mercado de valores mobiliários robusto". Cf. COMISSÃO DE VALORES MOBILIÁRIOS. Relatório de Análise da Superintendência de Desenvolvimento do mercado (SDM) à audiência pública n. 07/2008. 7 dez. 2009. Disponível em: $<$ http://goo.gl/C6U5tp>. Acesso em: 14 jun. 2015, p. 58.

${ }^{48}$ Esta forma de apresentar a remuneração foi uma proposta da AMEC e do IBGC. Cf. COMISSÃO DE VALORES MOBILIÁRIOS. Relatório de Análise da Superintendência de Desenvolvimento do mercado (SDM) à audiência pública n. 07/2008. 7 dez. 2009. Disponível em: <http://goo.gl/C6U5tp>. Acesso em: 14 jun. 2015, p. 59.

${ }^{49}$ Cf. COMISSÃO DE VALORES MOBILIÁRIOS. Relatório de Análise da Superintendência de Desenvolvimento do mercado (SDM) à audiência pública n. 07/2008. 7 dez. 2009. Disponível em: <http://goo.gl/C6U5tp>. Acesso em: 14 jun. 2015, p. 58.
} 
listada (TEKA) levou, individualmente, a norma para apreciação do Poder Judiciário. Nesse caso, já há decisão final.

O IBEF muniu-se de pareceres de dois importantes juristas brasileiros, um da área de mercado de capitais (Nelson Eizirik) e outro da área constitucional (Luís Roberto Barroso). O entendimento desses juristas e os argumentos da petição inicial apontam a invalidade da norma, por três razões.

Primeiro, a CVM não teria competência para promulgar tal regra. O raciocínio é o seguinte: a Lei 6.385, no art. 22, § $1^{\circ}$, confere competência à CVM para expedir normas sobre “natureza das informações que devam divulgar" (item I) e sobre "informações que devem ser prestadas por administradores, membros do conselho fiscal, acionistas controladores e minoritários, relativas à compra, permuta ou venda de valores mobiliários emitidas pela companhia e por sociedades controladas ou controladoras” (item II). A partir desses dois dispositivos, concluem que a competência da CVM é exclusivamente nas matérias enumeradas no item II e nenhuma outra. Por consequência, a nova regra de divulgação estaria contrária ao princípio da hierarquia de normas ${ }^{50}$. Além disso, o tema das informações sobre remuneração já estaria disciplinado na Lei das S.A. (artigos 152 e157) e não há qualquer determinação para divulgação pública de informações sobre remuneração dos administradores, as quais são de exclusivo interesse dos acionistas ${ }^{51}$. Se a lei não fez tal exigência, não caberia à CVM fazer.

Segundo, a nova regra estaria violando direitos individuais da intimidade, vida privada e sigilo de dados, previstos no art. $5^{\circ}$, incisos X e XII, da Constituição Federal. Reconhece-se que os direitos individuais não são absolutos, mas no caso não existiria fundamento em outra norma constitucional para que houvesse restrição aos direitos individuais ${ }^{52}$. Fez-se também paralelo com a divulgação de remuneração dos funcionários públicos. Mas a conclusão é que a publicidade deste tipo de remuneração estaria justificada por viabilizar controle social por parte da população que paga tributos ${ }^{53}$. Já para a divulgação da remuneração dos executivos de companhias abertas, a informação adequada aos investidores do mercado de valores mobiliários não teria status constitucional, sendo um interesse menor se comparado à proteção do direito à intimidade e à

\footnotetext{
${ }^{50}$ Resposta ao quesito $1^{\circ}$ do Parecer de Nelson Eizirik, p. 22-26, e ideia exposta às páginas 2 a 11 do Parecer de Luís Roberto Barroso.

${ }^{51}$ Parecer Nelson Eizirik, Resposta ao quesito $2^{\circ}$.

52 Parecer de Luís Roberto Barroso, p. 15.

${ }^{53}$ Parecer de Luís Roberto Barroso, p. 16.
} 
privacidade $^{54}$. A informação sobre remuneração é tratada em alguns momentos como mera curiosidade alheia ${ }^{55}$.

Terceiro, a petição inicial do IBEF sugeria que executivos seriam expostos a riscos, tendo em vista problemas sociais de segurança pública do País. Os juristas também argumentaram que a questão cultural não poderia ser desprezada, pois não haveria o costume de o brasileiro divulgar quanto se ganha, chamando este tema de "tabu social"56.

A CVM, por sua vez, na sua defesa, trouxe argumentos de ordem econômica, como a importância da norma para a tomada de decisão sobre investimento. Indicou que a remuneração dos administradores relaciona-se com os incentivos financeiros dados aos administradores das companhias abertas e à tomada de risco ${ }^{57}$. Também defendeu a necessidade de o Brasil ter padrões de transparência mínimos adotados no mercado internacional, para evitar que o País ficasse em uma posição inferior no mercado de capitais internacional. Além disso, mencionou que a regra foi um “compromisso assumido internacionalmente pelo Brasil em decorrência das reuniões de cúpula do G 20 e perante a Organização Internacional das Comissões de Valores (IOSCO)”58.

O Judiciário se posicionou de maneira antagônica nas diversas instâncias, em decisões vinculadas aos inúmeros recursos processuais de que as partes lançaram mão ${ }^{59}$. Além disso, os efeitos imediatos da regra foram suspendidos por meio de liminar no caso IBEF, sobre o qual ainda não há decisão final. Já no caso TEKA, a última palavra do Judiciário foi favorável à CVM. Portanto, a concessão de liminares e a demora para a resolução do conflito pode acabar prejudicando a atividade regulatória, ainda que a decisão da agência reguladora prevaleça ao final.

\footnotetext{
${ }^{54}$ Parecer de Luís Roberto Barroso, p. 20.

55 Parecer de Luís Roberto Barroso, p. 13. O presidente da Abrasca, Antonio Castro, manifestou-se no seguinte sentido: "Nos parece mais uma questão de curiosidade do que efetivamente de necessidade do investidor". Gazeta Mercantil, 2 de abril de 2009.

${ }^{56}$ Petição inicial, p. 19. Disponível em: <http://s.conjur.com.br/dl/peticao-suspensao-in-480-cvm.pdf>. Acesso em: 11 jun. 2015.

57 Cf. BRASIL. Superior Tribunal de Justiça. AgRg na suspensao de liminar e de sentença $n^{\circ} 1.210-R J$ (2010/0049852-0). Agravante: Comissão de Valores Mobiliários - CVM. Agravado: Instituto Brasileiro dos Executivos de Finanças - IBEF Rio de Janeiro. Relator: Ministro Ari Pargendler. Julgado: 1 set. 2010. Disponível em: <http://goo.gl/9Kusci>. Acesso em: 14 jun. 2015, p. 2-3. Literalmente: "permitir aos acionistas e aos potenciais investidores que compreendam, por meio delas [informações], toda a dinâmica de incentivos dados à administração, bem como avaliem a razoabilidade dos montantes e da concentração das recompensas, tudo isso cotejado com as informações divulgadas pelas demais companhias”.

${ }^{58}$ BRASIL. Superior Tribunal de Justiça. AgRg na suspensao de liminar e de sentença $n^{\circ} 1.210$ - RJ (2010/0049852-0). Agravante: Comissão de Valores Mobiliários - CVM. Agravado: Instituto Brasileiro dos Executivos de Finanças IBEF Rio de Janeiro. Relator: Ministro Ari Pargendler. Julgado: 1 set. 2010. Disponível em: <http://goo.gl/9Kusci>. Acesso em: 14 jun. 2015.

59 Para informações sobre os recursos, ver ficha do caso, disponível em: <https://goo.gl/flNCbc>. Acesso em: 11 jun. 2015.
} 
Considerando-se que as decisões no caso IBEF foram apenas liminares (i.e., apenas julgaram se a decisão deveria ou não ter efeitos até o julgamento da ação), vale apontar a forma pela qual o Judiciário considerou, na análise preliminar, o elemento do periculum in mora. Ou seja, qual foi a justificativa para mostrar que havia a necessidade de sustação da regra para impedir a lesão ou perecimento de direitos até o término do processo. Nas diversas decisões contrárias à divulgação da informação, que asseguram a liminar até os dias de hoje, entendeu-se a inadequação da norma com base em aspectos locais. Foi apontado o problema da divulgação de altas cifras em "um país de imensas desigualdades sociais e com alto índice de violências”60 e afirmou-se, quanto à existência dessa regra em outros países, que "não é de molde a importar, automaticamente, normas sem a necessária adequação [...]”. Ademais, os danos aos direitos individuais constitucionalmente protegidos com a divulgação da informação seriam evidentes para os julgadores. Já os prejuízos para o mercado de valores mobiliários são ou negados ou considerados como algo de difícil verificação.

Nas decisões liminares favoráveis à transparência, cita-se a importância da regulação internacional para o aperfeiçoamento do quadro regulatório brasileiro, e abomina-se o interesse egoístico de guardar a informação. O drama local de segurança social é reconhecido, mas é alocado a todos os cidadãos brasileiros, em especial nos grandes centros urbanos. Portanto, o problema da segurança não seria exclusivo de executivos que teriam suas contas abertas ao grande público. Esse é o teor da decisão final, transitada em julgado, do Tribunal Federal da $2^{a}$ Região no caso TEKA, e no agravo de instrumento do Caso IBEF, cujos efeitos estão suspendidos até os dias de hoje ${ }^{61}$.

Atualmente, com base na liminar do caso IBEF (popularmente conhecida como "liminar IBEF”), aproximadamente $28 \%{ }^{62}$ das companhias abertas não divulgam informações sobre a remuneração dos seus administradores. Apesar de ainda não haver decisão definitiva nesse caso, a demora da prestação jurisdicional final afeta o funcionamento do mercado. Não há duvidas que o Poder Judiciário tem o potencial de participar da regulação do mercado, ainda que não o faça, com frequência, por falta de demanda. Quanto ao seu conteúdo, as decisões liminares acenam para um

\footnotetext{
${ }^{60}$ Estudos que trabalharam este argumento da segurança e violência da decisão liminar do caso IBEF incluem: (a) ARGUELHES, Diego Werneck; PARGENDLER, Mariana. Custos colaterais da violência no Brasil: Rumo a um Direito Moldado pela Insegurança? Revista Direito GV, 2013; (b) COSTA, Cristiano M. et al. Violence-related costs and disclosure: why are some firms unwilling to disclose executive's compensation? FGV Conference, 34th Meeting of the Brazilian Econometric Society. Oct. 2012. Disponível em: <http://goo.gl/uMq6Sn>. Acesso em: 14 jun. 2015 ; e (c) BARROS, Lucas Ayres B. de et al. Facing the Regulators: Non-Compliance with Detailed Mandatory Compensation Disclosure in Brazil. Emerging Markets Finance and Trade, 51:sup2, S47-S61, 2015.

61 Nesse, as partes interpuseram Recurso Especial e Recurso Extraordinário e conseguiram efeito suspensivo, garantindo temporariamente o direito de não revelar a informação exigida pela CVM.

${ }^{62}$ Este percentual está apontado em BARROS, Lucas Ayres B. de et al. Facing the Regulators: Non-Compliance with Detailed Mandatory Compensation Disclosure in Brazil. Emerging Markets Finance and Trade, 51:sup2, S47-S61, 2015, p. 32.
} 
entendimento de que direitos individuais se sobrepõem à política de elevar o nível de informações ao mercado, especificamente sobre a divulgação da remuneração dos administradores de companhias abertas.

\section{A FUNÇÃO REGULADORA DO PODER JUDICIÁRIO NO MERCADO DE VALORES MOBILIÁRIOS BRASILEIRO}

O caso proposto para análise dá algumas informações sobre as três perguntas explicitadas no início do texto: (i) Quando grupos de interesses vão ao Poder Judiciário? (ii) Como eles acessam o Poder Judiciário? e (iii) Qual é o impacto da litigância envolvendo as agências reguladoras (direta ou indiretamente) na regulação e no quadro regulatório?

\subsection{QUANDO GRUPOS DE INTERESSES VÃO AO PODER JUDICIÁRIO?}

Nos últimos anos houve intensa atividade da CVM na criação de regras, em especial nas obrigações de transparência das companhias abertas, com as Instruções CVM 400/2003 (Prospectos de Emissão) e 480/2008 (Formulário de Referência). De todas as novas informações exigidas, que foram muitas, a única questão levada ao Judiciário foi a divulgação dos números referentes à remuneração dos administradores. Essa informação, sem dúvida, é a única que atinge diretamente o interesse da alta cúpula na tomada de decisão das companhias abertas.

O caso sugere que o Judiciário, em temas do mercado de valores mobiliários, foi chamado a controlar a atividade regulatória da CVM quando direitos individuais de pessoas físicas foram colocados em xeque. Esta afirmação, no entanto, não pode vir desconectada do processo de evolução dos padrões de boa governança corporativa no Brasil, que também teve fortes inspirações nos foros internacionais.

Como mencionado acima, tal evolução iniciou-se de maneira voluntária para as companhias, com a iniciativa da BM\&FBovespa de criar níveis diferenciados de governança corporativa. Não houve aderência a esses níveis por parte de todas as companhias, mas sim, principalmente, das companhias que estavam acessando o mercado pela primeira vez. Assim, há companhias listadas que ainda hoje se submetem apenas às exigências da legislação estatal societária de 1976. As reformas de padrões contábeis e de transparência da CVM, por sua vez, por serem normas estatais cogentes, aplicam-se a todas as companhias, inclusive àquelas que não guardam tanta simpatia com os padrões de governança corporativa defendidos internacionalmente. 
Estudo sugere que companhias que se beneficiam da "liminar IBEF" são aquelas que têm também fraca governança corporativa ${ }^{63}$.

Portanto, considerando que é incomum o questionamento, no Poder Judiciário, do poder normativo da CVM, a pergunta sobre quando o grupo de interesses vai ao Judiciário pode não ter relação apenas com a violação de direitos individuais. Vai além. Está combinada com o interesse de usar o mecanismo de mover a ação judicial com a intenção de garantir os status quo, i.e., manter opacidade frente à evolução regulatória. Aproveita-se a possibilidade da sensibilização do Poder Judiciário com a proteção de direitos individuais para proteger atores de efeitos individualmente sentidos de uma nova norma. E, por fim, aproveita-se também do sistema processual brasileiro, com várias instâncias de análise de uma mesma questão, para eventualmente protelar a aplicação da regra e beneficiar-se, ainda que temporariamente, da não obrigação de cumpri-la. Isso decorre do fato de uma medida cautelar tender a se estender por um longo período de tempo de tramitação no Poder Judiciário.

\subsection{COMO OS GRUPOS DE INTERESSE ACESSAM O PODER JUDICIÁRIO?}

No caso analisado, houve duas vias escolhidas para acessar o Judiciário, sendo o resultado diferente em cada uma delas. A primeira via foi uma ação coletiva proposta pela associação de classe dos executivos filiados ao IBEF. Nessa ação, em sede liminar, manteve-se a possibilidade de manutenção do sigilo, considerando o efeito suspensivo que se deu ao Recurso Especial e Extraordinário. A segunda via foi uma ação individual proposta por uma empresa (TEKA). O resultado definitivo foi a obrigatoriedade da divulgação. O apelo à proteção dos direitos individuais por apenas uma empresa não obteve resposta positiva, enquanto o ajuizamento de ação que afeta um grupo maior de empresas (assim é o caso IBEF) se beneficia em aguardar o juízo final sem se submeter à nova regra de transparência.

\footnotetext{
${ }^{63}$ Cf. BARROS, Lucas Ayres B. de et al., op. cit. Esses autores apontam que as empresas que não seguem os padrões de compliance são listadas nos dois principais segmentos da BM\&FBovespa. De toda forma, no relatório do IBGC (relatório 2012, p. 30), indica-se que as companhias listadas no Novo Mercado estão em menor número na utilização da liminar IBEF. Isto já aparecia no ano anterior.
} 


\subsection{QUAL É O IMPACTO DA LITIGÂNCIA ENVOLVENDO AS AGÊNCIAS REGULADORAS (DIRETA OU INDIRETAMENTE) NA REGULAÇÃO E NO QUADRO REGULATÓRIO?}

Essa é a pergunta mais interessante a ser respondida com o caso aqui analisado. Ela traz elementos para se pensar sobre dois pontos relevantes na regulação do mercado de capitais brasileiro. Primeiro, como uma instituição local (que não participa nos foros internacionais) ${ }^{64}$ pode interferir no processo de internalização de padrões internacionais de regulação do mercado ${ }^{65}$. $\mathrm{O}$ segundo ponto relaciona-se com a ponderação a ser feita entre interesses individuais locais e políticas regulatórias que pretendem o desenvolvimento do mercado de valores mobiliários.

Milhaupt e Pistor ${ }^{66}$, ao questionarem a efetividade dos transplantes dos padrões regulatórios, indicam que não se pode ignorar a participação de instituições locais no processo de convergência regulatória. As instituições locais servem à verificação de como esses padrões internacionais relacionam-se com outros interesses internos merecedores de proteção, bem como a verificar se as novas regras convivem em harmonia com o sistema jurídico.

Como acima demonstrado, os argumentos do IBEF e os pareceres dados por juristas brasileiros foram todos construídos para concluir pela negativa da possibilidade de a regra entrar no sistema brasileiro na forma como foi feita. Pretendeu-se desqualificar o poder normativo da CVM e apontar tecnicamente a incompatibilidade da regra administrativa com disposições constitucionais sobre direitos individuais.

No caso do IBEF, o Judiciário, a despeito de ainda não ter julgado definitivamente as questões técnicas, por estar em fase de juízo sumário em medida cautelar, fez uma escolha evidente pelos direitos individuais, ao sigilo, dos administradores. Verifica-se nas decisões que o direito individual de não ter devassada a vida financeira foi facilmente visualizado, o que inclusive justificou a concessão de medida liminar. O possível efeito da falta da informação para o mercado foi completamente ignorado e, até mesmo, incompreendido ${ }^{67}$.

\footnotetext{
${ }^{64}$ Conforme nota 26 acima, na IOSCO participam a CVM e outras SRO brasileiras (BM\&FBovespa, ANBIMA e CETIP).

${ }^{65}$ Sobre o papel do Judiciário diante da importação de modelos regulatórios Internacionais, ver: DUBASH, Navroz K.; MORGAN, Bronwen. Understanding the rise of the regulatory state of the South. In: Regulation \& Governance, 6, 2012, p. 261-281, e URUEÑA, Rene. The rise of the constitutional regulatory state in Colombia: the case of water governance. In: Regulation \& Governance, 6, 2012, p. 282-299.

${ }^{66}$ MILHAUPT, Curtis J.; PISTOR, Katharina. Law \& Capitalism: What corporate Crises reveal about legal systems and economic development around the world. Chicago: University of Chicago Press, 2008, p. 40.

${ }^{67}$ Neste sentido é a primeira decisão que deferiu a liminar. Cf. BRASIL. Justiça Federal. Seção Judiciária do Rio de Janeiro. Ação de Procedimento Ordinário n. 2010.5101002888-5. Autor: Instituto Brasileiro de Executivos de Finanças - IBEF Rio de Janeiro. Réu: Comissão de Valores Mobiliários - CVM. Juiz Firly Nascimento Filho. Julgado: 2 mar. 2010. Disponível em: <http://s.conjur.com.br/dl/liminar-in-480-cvm.pdf>. Acesso em: 14 jun. 2015, p. 4. Na segunda instância: BRASIL. Tribunal Regional Federal da Segunda Região. Agravo de Instrumento 2010.02.01.002742-8,
} 
Outra face desse mesmo posicionamento do Judiciário foi a relevância dada a aspectos locais (de segurança) e culturais (inexistência do hábito de revelar questões financeiras individuais). Isto nos faz refletir sobre os limites e a adequação da importação de regras globais para o sistema jurídico brasileiro.

Seja pela adequação do conteúdo da norma após a audiência pública, seja com a decisão liminar do Poder Judiciário, este caso demonstra que o transplante de regras aceitas internacionalmente, por si só, não é capaz de dizer como as coisas funcionarão. É preciso pensar em normas que poderão passar por instituições e terão que dialogar com outras regras e princípios do nosso sistema jurídico. O resultado pode não ter sido o desejado ou previsto no momento da edição da norma com inspiração exclusiva em mercados externos ${ }^{68}$. Os autores demonstram que padrões internacionais de governança corporativa ganham contornos próprios quando questionados em instituições locais.

Até a ocorrência desse caso, as discussões sobre boas práticas de governança corporativa restringiram-se a espaços fortemente relacionados com o funcionamento do mercado. Elas ocorrem no âmbito da BM\&FBOVESPA, da CVM e em foros empresariais e acadêmicos. Além disso, as normas de boa governança, em grande parte, têm caráter voluntário, uma vez que estão na regulação não estatal da BM\&FBOVESPA e na adoção espontânea por algumas empresas listadas nos níveis tradicionais. Com a edição da Instrução CVM 480, a obrigatoriedade tomou o lugar do simples voluntarismo da autorregulação, e, em especial, quando se fala em transparência de certas informações, houve o alinhamento a discursos internacionais sobre a obrigatoriedade da divulgação da remuneração dos administradores.

Há outro ponto interessante que o caso revela. A liminar judicial que dá direito à não divulgação trouxe uma situação não esperada pela CVM: algumas empresas, embora beneficiadas pela liminar, prestam a informação, e outras não. Assim, com o recurso ao Judiciário, normas cogentes foram afastadas temporariamente, dando espaço a efeito similar ao voluntarismo do nosso modelo de autorregulação. Ou seja, por meio do judiciário, uma série de empresas conseguiu tornar

interposto pela Comissão de Valores Mobiliários - CVM em face da decisão proferida pelo M.M. Juízo da $5^{\text {a }}$ Vara Federal da Seção Judiciária do Rio de Janeiro. Juiz convocado: Marcelo Pereira da Silva. Julgado: 6 mar. 2013. Disponível em: <http://goo.gl/8yWaVL>. Acesso em: 14 jun. 2015, p. 1. Na terceira e última instância: BRASIL. Superior Tribunal de Justiça. AgRg na suspensao de liminar e de sentença $n^{\circ} 1.210$ - RJ (2010/0049852-0). Agravante: Comissão de Valores Mobiliários - CVM. Agravado: Instituto Brasileiro dos Executivos de Finanças - IBEF Rio de Janeiro. Relator: Ministro Asfor Rocha. Julgado: 1 set. 2010. Disponível em: <http://goo.gl/9Kusci>. Acesso em: 14 jun. 2015, p. 4.

${ }^{68}$ Isto não é algo exclusivo do Brasil. Vide os casos da Mannesman, na Alemanha; da Livedoor, no Japão; da SK Corporation, na Coreia; da China Aviation Oil, na China e em Cingapura; e da Yukos, na Rússia - todos narrados na obra MILHAUPT, Curtis J.; PISTOR, Katharina. Law \& Capitalism: What corporate Crises reveal about legal systems and economic development around the world. Chicago: University of Chicago Press, 2008. 
a regra opcional (ainda que temporariamente). Quem quiser prestar informação, embora não seja obrigado, pode voluntariamente fazê-lo.

Mas há mais um elemento interessante do caso. Sendo os mercados sensíveis à informação prestada, é possível que os próprios investidores façam a avaliação da omissão dos dados. De fato, uma das respostas do mercado foi a orientação de voto dada pelos acionistas em assembleia, no sentido de rejeitar os pacotes de remuneração em assembleias gerais de empresas que não divulgassem informações completas. Houve um caso, noticiado na mídia, de não aprovação da proposta de remuneração por quase $60 \%$ dos acionistas presentes. Uma das razões para a votação contrária seria a não divulgação dos salários ${ }^{69}$. A segunda resposta veio das próprias empresas. Apesar de protegidas pela decisão cautelar, algumas delas deixaram de usar a "liminar IBEF" e passaram a divulgar os dados sobre remuneração dos seus administradores. De acordo com pesquisa realizada pelo Instituto Brasileiro de Governança Corporativa - IBGC,

O acompanhamento do percentual de empresas que se apoiaram na liminar do IBEF para a não divulgação das informações do item 13.11 do FR, referentes ao período de 2010 a 2013, aponta que houve uma redução da adesão das empresas a esta liminar comparando-se os dados referentes a 2010 e a 2011. Depois disso, observa-se uma tendência de crescimento da adesão das empresas ao uso da liminar.

Além disso, afirma que

Na análise da amostra classificada por tipo de controle, o mais alto percentual de empresas que se valeram da liminar em 2013 está entre as empresas de controle estrangeiro (31,6\%), seguidas pelas empresas de controle disperso (25,0\%). O percentual é nulo entre as empresas de controle estatal, sujeitas a leis de transparência mais rígidas ${ }^{70}$.

Essas duas respostas do mercado e das empresas apontam um limite do efetivo papel do Poder Judiciário de interferência na regulação do mercado de capitais, considerando a sensibilidade do mercado à informação e a existência de uma via reputacional relevante para as empresas que se financiam no mercado de valores mobiliários.

\section{CONCLUSÃO}

A partir da pesquisa realizada, é possível concluir que o Judiciário não participa constantemente da criação de regras administrativas da CVM. A análise do único caso relevante nos

${ }^{69}$ Cf. CARVALHO, Denise; TORRES, Fernando. Arrocho salarial. Valor Econômico, São Paulo, 4 maio 2011. Disponível em: <http://www.valor.com.br/arquivo/885631/arrocho-salarial>. Acesso em: 11 jun. 2015.

${ }^{70}$ Cf. IBGC. Remuneração dos Administradores - 2013. Disponível em: <http://goo.gl/1BCd15>. Acesso em: 14 jun. 2015, p. 6. Cf., ainda, Justiça proíbe CVM de imposição a companhias abertas. R7 Notícias, 23 de maio de 2013. Disponível em: <http://goo.gl/C1HhDZ>. Acesso em: 10 jun. 2015. 
últimos dez anos, no entanto, demonstra que há potencial de interferência do Judiciário, com a possibilidade de proteção de interesses individuais em contraposição a políticas regulatórias para desenvolvimento do mercado de valores mobiliários, especialmente em sede liminar.

Outro ponto interessante que o caso demonstra é que a decisão judicial de proteção dos direitos individuais em prejuízo às políticas regulatórias da CVM pode ser mitigada por iniciativas dos participantes do mercado, sejam os investidores, sejam as próprias companhias listadas. Isso ficou demonstrado na resposta dos investidores que votaram contrariamente ao pacote de remuneração, em assembleias posteriores, em companhias que se utilizaram da liminar para não divulgar os números dos salários dos seus executivos. Percebe-se a mitigação também no fato de algumas companhias terem deixado de se utilizar da liminar e de passarem a dar a informação ao mercado, assemelhando-se tal situação ao voluntarismo da autorregulação.

Por fim, o caso analisado indica que, no processo de internalização de padrões regulatórios internacionais, o Poder Judiciário pode ser a instituição local que faz a ponderação e analisa a adequação da regra ao sistema jurídico brasileiro.

\section{REFERÊNCIAS}

ARGUELHES, Diego Werneck; PARGENDLER, Mariana. Custos colaterais da violência no Brasil: Rumo a um Direito Moldado pela Insegurança? Revista Direito GV, 2013.

BARROS, Lucas Ayres B. de et al. Facing the Regulators: Non-Compliance with Detailed Mandatory Compensation Disclosure in Brazil. Emerging Markets Finance and Trade, 51:sup2, S47-S61, 2015.

BEBCHUK, Lucian A.; COHEN, Alma; SPAMANN, Holger. The wages of failure: executive compensation at Bear Stearns and Lehman 2000-2008. Yale Journal on Regulation, vol. 27, 2010, p. 257-282. Disponível em: <http://papers.ssrn.com/sol3/papers.cfm?abstract_id=1513522>. Acesso em: 14 jun. 2015.

BMF\&BOVESPA. Bolsa de Valores de São Paulo. Estudos para o Desenvolvimento do Mercado de Capitais. Desafios e oportunidades para o mercado de capitais brasileiro. Junho de 2010. Disponível em: <https://goo.gl/CMSy6C>. Acesso em: 14 jun. 2015.

. Bolsa de Valores de São Paulo. Relatório Anual - 2010. Disponível em:

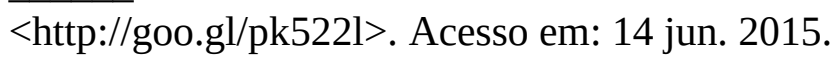

Bolsa de Valores de São Paulo. Relatório Anual - 2012. Disponível em: <http://goo.gl/U7zTsk>. Acesso em: 14 jun. 2015.

BRASIL. Constituição da República Federativa do Brasil de 1988. Diário Oficial da União, Brasília, 5 de outubro de 1988. 
Justiça Federal. Seção Judiciária do Rio de Janeiro. Ação de Procedimento Ordinário $n$. 2010.5101002888-5. Autor: Instituto Brasileiro de Executivos de Finanças - IBEF Rio de Janeiro. Réu: Comissão de Valores Mobiliários - CVM. Juiz Firly Nascimento Filho. Julgado: 2 mar. 2010. Disponível em: <http://s.conjur.com.br/dl/liminar-in-480-cvm.pdf>. Acesso em: 14 jun. 2015.

. Lei $\mathrm{n}^{0}$ 6.404, de 15 de dezembro de 1976. Dispõe sobre as Sociedades por Ações. Diário Oficial da União, Brasília, 17 de dezembro de 1976.

. Lei $\mathrm{n}^{0} 7.940$, de 20 de dezembro de 1989. Institui a Taxa de Fiscalização dos mercados de títulos e valores mobiliários, e dá outras providências. Diário Oficial da União, Brasília, 21 de dezembro de 1989.

Superior Tribunal de Justiça. AgRg na suspensao de liminar e de sentença $n^{\circ} 1.210-R J$ (2010/0049852-0). Agravante: Comissão de Valores Mobiliários - CVM. Agravado: Instituto Brasileiro dos Executivos de Finanças - IBEF Rio de Janeiro. Relator: Ministro Asfor Rocha. Julgado: 1 set. 2010. Disponível em: <http://goo.gl/9Kusci>. Acesso em: 14 jun. 2015.

. Tribunal Regional Federal da Segunda Região. Agravo de Instrumento 2010.02.01.0027428, interposto pela Comissão de Valores Mobiliários - CVM em face da decisão proferida pelo M.M. Juízo da $5^{\text {a }}$ Vara Federal da Seção Judiciária do Rio de Janeiro. Juiz convocado: Marcelo Pereira da Silva. Julgado: 6 mar. 2013. Disponível em: <http://goo.gl/8yWaVL>. Acesso em: 14 jun. 2015.

CARVALHO, Denise; TORRES, Fernando. Arrocho salarial. Valor Econômico, São Paulo, 4 maio 2011. Disponível em: <http://www.valor.com.br/arquivo/885631/arrocho-salarial>. Acesso em: 11 jun. 2015.

COMISSÃO DE VALORES MOBILIÁRIOS. Relatório Anual 2011. Disponível em: $<$ http://goo.gl/lPsyvi>. Acesso em: 14 jun. 2015.

Relatório de Análise da Superintendência de Desenvolvimento do mercado (SDM) à audiência pública n. 07/2008. 7 dez. 2009. Disponível em: <http://goo.gl/C6U5tp>. Acesso em: 14 jun. 2015.

COSTA, Cristiano M. et al. Violence-related costs and disclosure: why are some firms unwilling to disclose executive's compensation? FGV Conference, 34th Meeting of the Brazilian Econometric Society. Oct. 2012. Disponível em: <http://goo.gl/uMq6Sn>. Acesso em: 14 jun. 2015.

CREDIT SUISSE. A guide to the Brazilian economy - 2009. 11 set. 2009. Disponível em: $<$ http://www.credit-suisse.com/researchandanalytics>. Acesso em: 14 jun. 2015.

DUBASH, Navroz K.; MORGAN, Bronwen. Understanding the rise of the regulatory state of the South. In: Regulation \& Governance, 6, 2012.

EUROPEAN CORPORATE GOVERNANCE INSTITUTE. Executive Remuneration. 30 jun. 2003. Disponível em: <http://www.ecgi.org/remuneration/>. Acesso em: 14 jun. 2015. 
FERRAZ JUNIOR, Tércio Sampaio; MARANHÃO, Juliano Souza de Albuquerque; AZEVEDO, Paulo Furquim de. Inter-relações entre o processo administrativo e o judicial sob a perspectiva da segurança jurídica no plano da concorrência econômica e da eficácia da regulação pública. 2010. Disponível em: <http://www.niajajuris.org.br/images/documentos/rfusp.pdf>. Acesso em: 14 jun. 2015.

FINANCIAL STABILITY FORUM. FSF Principles for Sound Compensation Practices. 2 April 2009. Disponível em: <http://goo.gl/t7Lxnx>. Acesso em: 14 jun. 2015.

GHIRARDI, José Garcez; PALMA, Juliana Bonacorsi de; VIANA, Manuela Trindade. Posso fazer um trabalho inteiro sobre um caso específico? In: QUEIROZ, Rafael Mafei Rabelo; FEFERBAUM, Marina. Metodologia jurídica: um roteiro prático para trabalhos de conclusão de curso. São Paulo: Saraiva, 2012, p. 178-190.

GILSON, Ronald J.; HANSMANN, Henry; PARGENDLER, Mariana. Regulatory Dualism as a development strategy: corporate reform in Brazil, the United States, and the European Union. In: Stanford Law Review, vol. 63, March/2001, n. 3, p. 475-537.

IBGC. Remuneração dos Administradores - 2013. Disponível em: <http://goo.gl/1BCd15>. Acesso em: 14 jun. 2015.

IOSCO. Corporate Governance in Emerging Markets - Report from Emerging Markets Committee of the IOSCO, December 2007. Disponível em: <http://goo.gl/C1HhDZ>. Acesso em: 14 jun. 2015.

Principles for Periodic Disclosure by Listed Entities - Final Report, February 2010. Disponível em: <http://goo.gl/hYhUXu>. Acesso em: 14 jun. 2015.

Justiça proíbe CVM de imposição a companhias abertas. R7 Notícias, 23 de maio de 2013. Disponível em: <http://goo.gl/C1HhDZ>. Acesso em: 10 jun. 2015.

MACHADO, Maíra Rocha. Contra a departamentalização do saber jurídico: a contribuição dos estudos de caso para o campo direito e desenvolvimento. In: SILVEIRA, Vladmir Oliveira da; SANCHES, Sandra Naspolini; COUTO, Monica Bonetti. Desenvolvimento nas ciências sociais. O estado das artes. Direito e desenvolvimento no Brasil do século XXI. Brasília: Ipea, Conpedi, 2013, p. 177-200. Disponível em: <http://goo.gl/UkgGJ1>. Acesso em: 6 fev. 2016.

MARIOTTO, Fabio Luiz; ZANNI, Pedro Pinto; MORAES, Gustavo Hermínio Salati Marcondes de. What is the use of a single-case study in management research? Revista de Administração de Empresas, vol. 54, ano 4, São Paulo, julho/agosto 2014. Disponível em: <http://goo.gl/B9tBF4>. Acesso em: 6 fev. 2016.Acesso em: 14 jun. 2015.

MATTOS FILHO, Ary Oswaldo; PRADO, Viviane Muller. Tentativas de desenvolvimento do mercado acionário brasileiro desde 1964. In: PADUA LIMA, Maria Lúcia L. M. Agenda contemporânea. Direito e economia: 30 anos de Brasil, tomo 2. São Paulo: Saraiva, 2012.

MILHAUPT, Curtis J.; PISTOR, Katharina. Law \& Capitalism: What corporate Crises reveal about legal systems and economic development around the world. Chicago: University of Chicago Press, 2008. 
MORICEAU, Jean-Luc. What can we learn from a singular case like Enron? Critical Perspective on Accounting, n. 16, Elsevier, 2005, p. 787-796.

PITTA, André Grünspun. O Regime de Informação das Companhias Abertas. $1^{\text {a }}$ edição. Quartier Latin: São Paulo, 2013.

RACHMAN, Nora; PRADO, Viviane Muller; COELHO, Alexandre. Internalização dos padrões regulatórios no Brasil: o caso IOSCO. 2015. No prelo.

SANTANA, Maria Helena et al. Novo Mercado and its Followers: Case Studies in Corporate Governance Reform. Global Corporate Governance Forum, 2008. Disponível em: <http://goo.gl/3nsbcb>. Acesso em: 14 jun. 2015.

STAKE, Robert E. The art of case study research. London: Sage, 1995.

TANOUE, Luciana. O tabu da remuneração. Os aspectos culturais, sociológicos e psicológicos que explicam a recusa dos administradores de companhias abertas em ter sua remuneração revelada. In: Capital Aberto, Ano 7, n. 80, abril/2010, p. 32-36.

URUEÑA, Rene. The rise of the constitutional regulatory state in Colombia: the case of water governance. In: Regulation \& Governance, 6, 2012.

YIN, Robert K. Estudo de caso. Planejamento e métodos. Porto Alegre: Bookman, 2005.

\title{
JUDICIARY INTERFERENCE OVER THE REGULATION OF SECURITIES MARKET: THE CASE OF EXECUTIVES’ REMUNERATION DISCLOSURE IN BRAZIL
}

\begin{abstract}
This paper aims to shed light on the role of the Judiciary in the Brazilian capital markets regulation. The study is based on the analysis of the only important case in the last ten years that shows there is great potential for judicial interference. This interference, through injunctions, tends to favour the protection of individual rights over regulatory policies for the development of the securities market. However, the case shows that judicial decisions for the protection of individual rights contrary to CVM regulatory policies can be mitigated by initiatives of market participants, whether they are investors or listed companies. The case study suggests that in the process of internalizing international regulatory standards the judiciary may be the local institution to consider and analyse the suitability of rules in the Brazilian judicial system.
\end{abstract}

\section{KEYWORDS}

Judiciary. Securities Commission. IOSCO. Executive Remuneration. 